\title{
THEORETICAL APPROACH TO ONLINE MARKETING
}

Yakup DURMAZ ${ }^{1}$, Ahmet ILHAN ${ }^{2}$ and Ercan INCE ${ }^{3}$

${ }^{1}$ Faculty of Economics Administrative and Social Sciences, Hasan Kalyoncu University, Havalimanı Yolu Üzeri 8. Km. Gaziantep, Turkey.

${ }^{2}$ Phd.Student at Department of Bussiness Administration of Hasan Kalyoncu University.

${ }^{3}$ Phd.Student at Department of Bussiness Administration of Hasan Kalyoncu University.

\begin{abstract}
The Internet is one of the first things leading technological developments. It provides easy accessibility to the products. These kind of developments led businesses to use the Internet intensely in marketing. Thus, online marketing has started to develop and become one of the direct marketing techniques. Online marketing provides both businesses and customers with a great deal of easiness. Companies present customers with products, services and information in an untraditional way thanks to online marketing. Moreover, customers have had the advantage of following the developments and changes, also the access to the products and services easily. Other than the power of information access of the Internet, commerce network and distribution have appeared to be very efficient. In this regard, online marketing have been considered to be one of the tools of modern marketing in terms of reaching customers.
\end{abstract}

\section{Key Words}

The Internet; Online Marketing; Online Marketing Tools

\section{Council for Innovative Research}

\section{Peer Review Research Publishing System}

\section{Journal: INTERNATIONAL JOURNAL OF COMPUTERS \& TECHNOLOGY}

Vol. 14, No. 11

www.ijctonline.com, editorijctonline@gmail.com 


\section{Introduction}

The aim of this study is to reveal short information about online marketing which changes with developing internet technologies and its outlets. We will try to give an idea about position of online marketing in comparison with traditional marketing. Moreover, we will try to introduce popular online marketing techniques. Online marketingin globalizing world economy has gain strategic importance in terms of economic growth. Purpose of this study is to present online marketing with its basic aspects.

Marketing has reached the present day by passing through some stages. These stages are known as, according to classical differentiation, sale, marketing, social marketing and global marketing. When the basic reasons of these stages are examined, they are determined as 1) development and proliferation of technology and internet 2) increase of globalization and global competition 3) increase of education and knowledge level. With the help of technological development, especially proliferation of internet, globalization has appeared and world has become just a market. Again with the help of technological and global factors, communication has developed and people start to reach to whole world easily. This situation causes increment in educational and communicational level of the people.

\section{Appearance of Online Marketing}

Internet can be identified with its general meaning as network transfer information among computers with the participation of millions of people and organizations from all around the world (Birkan, 1998:29). Online marketing history, much as interwoven with Internet development, has appeared after a long time from occurrence of ARPANET, the first large-scale computer network which is started to work in 1969 (Gedik,2009:112).

Globalization cycle which has occurred with developments of Industrial revolution oblige firms to be involved in a harsh competition environment. Especially after $18^{\text {th }}$ centuryglobal marketcompetition environmentand financial, economic developments in world economy force firms to overseas expansion, making innovations and always developing their technologies (Yalçın, 2012:19). In addition to this, with developing information technologies, many new methods are used in the marketing field which is one of the core activity branches of many firms. The most common method is online marketing because it is the most suitable way of adapt to globalization. So this method is used by many firms around the world (Ekmekçi, Berber and Kutlu, 2009:12). As a result of developing electronic media and its qualities, firms has started to change some parts of their traditional marketing activities to this field. Growing internet environment causes changes in both traditional sense of management and daily shopping styles of people. Marketing activities, major topic of this study, have started to appear on the internet significantly and they cause to be formed a new sense of management which is named as online marketing. With developing electronic communication, temporarily rentable, panderer at all hours of day and night virtual offices has started to come into service instead of highly cost corporate offices with workers and office machinery in U.S.A and England. By this way, internet is used as communication and marketing tool and communication among distant offices is implemented safely, fast and cheapishly (Tağıyev, 2005: 27). Nowadays, with wide spearing online internet technologies usage, web marketing has started to become quite active marketing device (Jones, Malczyk and Beneke, 2012:4). Online marketing, especially with developing communication technologies, should not be seen as just a new outlet or a store in a different environment (Tağıyev, 2005: 27). Trade and marketing activities over internet lead to so many economic opportunities such as a new supply chain, product distribution service, decrease in product cost, direct sale and these opportunities emerge as a topic that firms should think about it (Yalçın, 2012:20). Therefore, we can conclude that creating web site and uploading it is the same with opening shutters and waiting (Tağıyev, 2005: 28). There is no such commercial activity cannot be done over internet no longer. From banking transactions, buying cinema, theater, sport tournaments ticketsto ordering food, there is a big proceeding world on the internet (Ekmekçi, Berber and Kutlu, 2009:12). So, if the firms want to perform successful marketing activities, they should make accurate and rationalist rating.

\section{Describing Web Marketing Conceptually}

It is started to be used so many terms such as "electronic commerce, online shopping, web marketing, electronic shopping, virtual shopping, online shopping and net economy" with using Internet effectively as direct marketing device. Common direction of all these terms is a commercial activity which is used in unreal, virtual environment or mutual communication made on the market and the consequence of this communication. These terms expressed as internet marketing or marketing over internet use internet and all other technologies related with internet to reach marketing aim and goal (Ünal, 2010:157).

Mathissen, (1995:37) describes online marketing in the most general sense as using Internet to gain; Odabaşı and Oyman, (2003:59) describe online marketing as using Internet and internet related digital technologies to accomplish marketing objectives and to support modern marketing sense(Koçoğlu and Özcan, 2010:24). Online marketing is described as transferring information electronically by using computer or similar device in digital platform and an area in which advertisement and shopping are done. (Jones, Malczyk and Beneke, 2012:4). 
Online marketing is identified as " a strategic process which is relating to developing products, rating, publicity and dispersion in target market oriented Internet environment" (Mucuk, 2004: 244). In other words, online marketing is identified as method that is going to give pleasure to both producer and consumer; with online activities, it is idea, product and service change enabler and it is going to organize and maintain consumer relations (Yalçın, 2012:20). Hence, searching for more alternatives by consumers and increasing questions and answers about products add a dimension to consumers. Thus consumers can use internet in every steps of buying process (Özcan, 2010:32). Because of all these reasons, online firms have chance to forward indigenous message to its potential consumers (Yükselen, 2013:215). Especially with the help of communication technologies, marketing over internet should be thought as not only a new outlet or a new store in different environment but also a new supply chain, product distribution service, decrease in product cost, direct sale, economic aspects and so many opportunities for firms (Eren, 2009:8).

\section{Transition from Traditional Marketing to Online Marketing}

Online marketing uses different methods and techniques from traditional marketing. Two major factors which identify direct marketing, which is named as a marketing framework trying to reach consumer the quickest and optimum way and minimizing cost of this way, are relationship between seller and consumers and expected behavior by seller (Eren, 2009:8). By this way, electronic communities which occur in internet environment are aimed. The apex of the direct marketing is showed as online marketing, namely marketing done in electronic environment with all opportunities of communication technologies. Qualitatively, while online marketing, likened to one of direct marketing techniques; telemarketing, uses different tools and techniques from traditional marketing, it is more general. Online marketing appear as a high technology oriented, fast and ever-growing method at the same time it uses traditional techniques (Eren, 2009:9). According to this approach, "in the future, success in global commercial market is going to be companies which produce highly valued, immediate supplier of consumers, various "virtual products" (Tağıyev, 2005: 28).

When we examine differences of online and traditional marketing from the aspects of basic marketing activities, we see four basic differentiations. According to this examination, differences between online marketing and traditional marketing are (Yalçın, 2012:22-23); advertisement, customer service, sale and marketing. When we examine marketing mix elements, in comparison with traditional marketing, online marketing shows difference mostly in promotion equipment. Most common publicity ways; creating web sites, enrolling pages about the sector, place add to search engines and different sites, promotion with e-mail, creating a network with online communities (Koçoğlu and Özcan, 2010:25). In this respect, online marketing of an industry which is in contact with sectors is thought as an important competitive advantage in globalizing markets. Consequently, current equipment's transformation in transition from traditional marketing to online marketing range as (Jones, Malczyk and Beneke, 2012:16-17);

- Substantial office- website

- $\quad$ Phone/Letter- E-mail

- Traditional Advertisement- Online Advertisement

- Questionnaire/Market Survey-Web Analysis

- $\quad$ Traditional PR studies- Web PR studies

E-mail, web analysis, online advertisement, website has great place in online marketing implementations and they are extremely used in communication between consumers and companies. Thus, companies have advantageous such as time, cost and competition thanks to interaction realized by online marketing.

\section{Development of Online Marketing in Turkey}

It is seen that online marketing enter into the development process with starting commercial activities over internet in Turkey. In this process, commercial activities made over internet have increased interaction among sectors. Accordingly, Alba (1997) and Ody (1999) state that internet is one of the best suitable environment for marketing commercial products (Ekmekçi, Berber and Kutlu, 2009:13). Also, with the idea of being most potential pulpit, internet figures much more than being distribution channel and pulpit. In this manner, many product's and services' traditional sector practices have started to be developed on the internet at the present time (Koçoğlu and Özcan, 2010:24). At the same time, with spreading of internet access in our country, it has considerable increase on using internet by people and institutions. According to research results, almost each institution has internet connectivity. Thus, all manner of companies start to have a web page. Some institutions send questionnaire or form to their customers who contact with the company in a sort of way. With the help of information obtained from questionnaires and forms, companies send informing messages to e-mail addresses of people (Ünal, 2010:160). In this way, both institutions and customers have an attitude to guide and support each other for commercial activities made over internet.

First application of online marketing in Turkey is known as Electronic Funds Transfer (EFT) which has started among Merkez Bank and the other banks in 1992. IGEME is chosen as commercial hub of Ankara by UNCTAD (United Nations Conference on Trade and Development) in 1995 and this is known as second step. As part of this study, TÜBITAK started TUANA (Informatics Substructure Plan of Turkey) in the same year (Yalçın, 2012:24). This project reveals internet and informatics substructure of Turkey and forms starting point of public's attitude towards the topic. ETKK (Electronic Trade Coordination Council) that has delegates of Competition Authority and public, private sector, university participants is established within the supreme council for science and technology. A report is prepared by ETTK and in this report there is "Preparation of Legal Infrastructure" title. One advice from this title is stated as "operators determination in 
electronic payment systems; in terms of contracts made among these operators, legal rules determination according to policies in Competition Law" (Eren, 2009:10). These developments cause increment in number of companies that give consultancy service about electronic trade (Tağıyev, 2005:42).

Preliminarily, online marketing was generally B2C (Business to consumer- e-trade from firm to consumer) in Turkey. Electronic commerce divides into two bazaars conceptually. These are categorized as B2B (Business to business) and B2C (Business to consumer) markets. The most known web based commerce activities is B2C (Business to customer) system. B2C market consists of online marketing web pages and virtual stores (Yalçın, 2012:24-25). In Turkey, online marketing has used $\mathrm{B} 2 \mathrm{C}$ in general. The most popular products in this area is ticket sale with \%71, electronic products with $\% 11$, flower with $\% 8$, CD with $\% 6$, food with $\% 5$ and clothing with $\% 3$ (Eren, 2009:11).

\section{Development of Online Marketing on the World}

On the world, online marketing has started to develop with developing and improving internet technologies. In parallel with developing online marketing, increment incomputer and internet usage has affected the user number of electronic environment in the dynamic and ever-growing markets (Yalçın, 2012:26). Increment in user number enables rise of online marketing and trading size. In addition to this, this increase enables to do this commerce in all fields.

Development process of online marketing has started to be used extremely in 1996 by institutions. Of course, it can be said that there have been some activities before this year. However, these activities are either intranet or extranet which is closed activity used by institutions to communicate among each other or specific customers (Eren, 2009:4). United States of America (USA) leads online marketing and its works in the world. USA is the most electronic commercial (commerce made by television, telephone, internet etc.) country in the world (Yalçın, 2012:27). Quantity of electronic commerce made in USA is much more than the other European countries. The best opportunity of USA firms is preparing and introducing their products 260 million people who is speaking the same language and share same culture (Tağıyev, 2005:39).

Online marketing provides a new market which is tried to be explained with online, virtual and electronic commerce and has occurred as consequence of institutions, electronic environment's changing attempts available information flow to product and service flow (Adıgüzel, 2010:10). At the same time, in today's world, with developing network technologies and information systems in terms of substructures and security systems, online commerce and marketing are seen as inseparable part of life. Thus, developments in computer and communication technologies has started to bring marketing size unforeseen levels.

\section{Tools used in Online Marketing}

Generally, firms use these tools while they are doing their online marketing activities:

\subsection{Search Engines}

While there are millions web pages on the internet, if the searching address is not known then search engines (www.yahoo.com, www.google.com, www.yycos.com) are used. In this existing system, while sites range, there are relevant advertisements in a part. For example, when we write "Beyzbol" in search engine, besides so many information about it, we can also see so many relevant advertisement. At the same time, some factors come to forefront to searching consumers for entering firms' web site (Adıgüzel, 2010:13).

Search engine is known as a mechanism used for searching content in internet. It consists of three components: web robot, search index and user interface. Search results are given as a list consist last clicked web sites (Yalçın, 2012:29). In addition to this, indexes and links given by other firms to relevant firm affect the order (Eren, 2009:14).

\subsection{Web Sites}

Web sites which are shown as commercial face of firms are techniques that enabling uninterrupted communication to people. As an online marketing instrument, web sites' best advantage is mutual consumer interaction evaluating and communication individualization according to existing interest. Accomplishedly prepared website can change from information about services and products to information prospecting way of interests and shopping attitudes of consumers (Adıgüzel, 2010:13).

Commercial web sites prepared to give facilitative service to users about products and services can cause wasting time because of their number increment even they are on internet. So search engines have become important tools for satisfying the needs of consumers, researchers, products, services,information and technical support (Yalçın, 2012:29).

\subsection{Banner}

There are colorful animations on popular web sites, generally up side of the page, they are named as banner and hyperlinks, occurs on banner, help to direct relevant web site. Banner advertisements are seen as the first step of directing target audiences to relevant web site of firm (Adıgüzel, 2010:11-12). In this way, with developing internet and information technologies, banner on internet has diversified. Banners are web sites of firms which are prepared to introduce service and products in design templates of popular firms and generally include a slogan and attractive animations (Yalçın, 2012:30). Attractive and well-prepared banner advertisement with successful web site provides to be known of firm's web site by target customers. Banner advertisements are easier and cheaper than newspaper, magazine, 
television and the other advertisements. However, because of low view and click number, generally it is not preferred by professionalmarketers(Eren, 2009:13).

\subsection{Electronic Mail}

Electronic mail marketing, one of the marketing techniques, is used as sending advertisements and publicity to previously listed target customers (Ünal, 2010:159). Electronic mail is an advantageous technique because instead of waiting target customers on for marketing, it can reach them directly (Yalçın, 2012:30). Also, customers' needs and wishes, customer satisfaction and customer attitudes can be understood with electronic mails. With the help of this, customers are categorized according to their needs, wishes and attitudes and firms apply different strategies, marketing activities (Adıgüzel, 2010:14).

\section{Conclusion}

Developments in information and communication technologies cause solid and radical changes in both market and customer structure. In new information based technology, internet has become the most important marketing tool which provides to firms and customers attaining their aims fast and economically. In time, internet developments around the world gain important advantages such as money and time to both managements and customers. In this manner, customers has chance to reach intended product and services with less time and cost and they can compare alternatives easily. So, with extremely usage and advantages of internet, managements have started to use it as a marketing tool. For online marketing, firms start to use electronic mails, web sites, banners and search engines and they start to develop strategies. However, in online marketing the most important factor to be successful in activities is identifying customers' needs and wishes as it is in traditional marketing. For this purpose, online marketing speeds up studies such as marketing techniques, advertisement, campaign or informing. A firm that wants to be successful in online marketing has to guess target customers' attitudes and possible reasons of these attitudes. In this way, providing promotion, becoming first firm come to mind and being mentioned positively in customers' mind are very important factors for the success of firm. While there are competitors' of an online marketing enforcer firm in physicalenvironment, being in second or lower level places in competition is going to create some difficulties to reaching consumers. So, for providing easy access to web site and shopping, firms have to advertise apart from virtual environment and provide customer traction.

The most important point of successful online marketing activities is making customer analyzing correctly. This topic has great importance in online marketing activities. Existing market customer analysis cannot show the same effect in general when they are used in new markets. So, product and service presentation with different marketing activities to the customer groups with different cultures is the most important thing. Customer attitudes shaped by many factors, show up as consequence of different customer attitudes from two different countries in which these factors change.Consequently, while online marketing has some advantages such as giving chance to consumer for time, product, cost and firm comparison; it has disadvantages. For example, consumer cannot see the product before buy; there are security application problems in electronic activities and problematic topics about validity of electronic contracts.

\section{Kaynakça}

Adıgüzel, A.T. (2010). Sanal Mağaza Atmosferini Etkileyen Özellikler ve Tüketici Tercihleri Üzerindeki Rolü: Online Tüketiciler Üzerine Bir Araştırma, Balıkesir Üniversitesi Sosyal Bilimler Enstitüsü Basılmamış Yüksek Lisans Tezi, Balıkesir.

Çolakoğlu, O.E. , Ataman, C. (2007). "İnternetten Pazarlama:İzmir İli Seyahat Acenta Yöneticilerinin Bakış Açısı", Adnan Menderese Üniversitesi, Seyahat ve Turizm Araştırmaları Dergisi, Güz, ss.171-195.

Ekmekçi,R. Berber, S. ve Kutlu, Ö. (2009). "Spor Pazarlamasında İnternet Kullanımı: Türkiye Futbol Süper Ligi Takımlarının Ağ Ortamında Pazarlama Açısından İncelenmesi", Atatürk Üniversitesi Beden Eğitimi ve Spor Bilimleri Dergisi, cilt:11, sayı:4, ss.11-20.

Eren, K. (2009). İnternet Tüketicisinin Satın Alma Davranışlarının İncelenmesi Üzerine Bir Araştırma, Çukurova Üniversitesi, Sosyal Bilimler Enstitüsü, Yayınlanmamış Yüksek Lisans Tezi, Adana.

Gül, H. ve Boz, M. (2012). "İnternet Ortamında Pazarlama, Online Rezervasyon; Şehirlerarası Otobüs Firmaları Üzerine Bir Araştırma", İnternet Uygulamaları ve Yönetim Dergisi, 3(1), ss.5-30, DOI: 10.5505/iuyd.2012.76486 İyiler, Z. (2009). Elektronik Ticaret ve Pazarlama İhracatta İnternet Zamanı:1, Ankara:Dış Ticaret Müsteşarlığı İhracatı Geliştirme Etüd Merkezi.

Jones, A.T. , Malczyk, A. ve Beneke, J. (2012). Internet Marketing, Published by GetSmarter Under The Creative Commons BY-NC 3.0. Koçoğlu, D. ve Özcan, S.O. (2010). "İşletmelerin İnternet Pazarlama Faaliyetleri: Doğal Taş ve Mermer Sanayinde Bir Araştırma", İnternet Uygulamaları ve Yönetim Dergisi, 1(1), ss.23-37, DOI: 10.5505/iuyd.2010.33042 Korkmaz, N. (2002). Sorularla İnternet ve E-Ticaret Rehberi, İstanbul:İstanbul Ticaret Odası: Yayın No: 2002/37.

Mucuk, İ. (2004). Pazarlama İlkeleri ve Örnek Olaylar, İstanbul, Türkmen Kitapevi.

Özcan, S.O. (2010). "İnternet Pazarlama Faaliyetlerinde Tüketici Satın Alma Karar Süreci", İnternet Uygulamaları ve Yönetim Dergisi, 1(2), ss.29-39, DOI: 10.5505/iuyd.2010.58066 Saylor URL: http://www.saylor.org/books, eMarketing-The Essential Guide to Online Marketing. 


\section{ISSN 2277-3061}

Tağıyev, R. (2005). Elektronik Ticaret ve İnternet Üzerinden Pazarlama, Ankara Üniversitesi Sosyal Bilimler Enstitüsü, Yayımlanmamış Yüksek Lisans Tezi, Ankara. Ünal, S. (2010). "İnternet Üzerinde İzinli Pazarlama Yaklaşımı", Öneri Dergisi, cilt:9, 34(17), ss.155-162.

Yalçın, F. (2012). İnternet Pazarlamasında Müşteri Memnuniyeti:Günün Fırsatları Üzerine Bir Uygulama, Atılım Üniversitesi, Sosyal Bilimler Enstitüsü Basılmamış Yüksek Lisans Tezi, Ankara.

Yükselen, C. (2013). Pazarlama İlkeler-Yönetim-Örnek Olaylar,10.Baskı, Ankara: Detay Yayıncılık. 